\title{
Extent Of Measurement And Disclosure Of Environmental Information In Financial Reports Under (IFRS \& IAS) For Yemeni
}

\author{
ali abdo DHAIF ALLAH ${ }^{1,2}$, Salmane BOUREKKADI ${ }^{3}$, Aziz BABOUNIA ${ }^{2}$, Saliha ELHAKMI ${ }^{4}$ \\ ${ }^{1}$ Amran University _Republic of Yemen \\ 2 ENCG, Ibnt Tofail University, Morocco \\ 3 Université de Poitiers, Poitiers France \\ 4 ENCG, Mohammed Premier University, Morocco
}

Aliabdosaleh.dhaifallah@uit.ac.ma.

\begin{abstract}
The study aims to determine the requirements for the disclosure of environmental information in the financial statements in light of international accounting standards and to study and determine the degree and nature of disclosure of environmental information in the financial statements of the sample companies, and the importance of environmental information in making decisions about setting plans and objectives and drawing policies that aim to protect and sustain the environment as It represents the comprehensive container of the elements of natural wealth, based on the information announced in the annual reports of the sample companies, which include an industrial and forestry company, and it was selected from the most environmentally sensitive sectors and the most impacting on the environment.
\end{abstract}

Using the content analysis method, which will be the main measurement tool for the research, where the disclosure scale will be prepared using this method and in a similar way to the scale (1982, Wiseman), which includes 18 axes of environmental disclosure within 6 main axes covering all aspects of the environmental performance of the company. The results of the study showed that disclosure in the sample companies is restricted by what is imposed by the standard accounting system with regard to the disclosure of fuel or production waste, as the environmental accounting applications in industrial and strategic companies in Yemen did not take sufficient attention, and this comes as a result of the lack of awareness of industrial companies and their weak contribution to the responsibilities that should be borne in the field of environmental protection and society.

This study represents the theoretical framework for understanding the nature of environmental accounting and reporting by providing a detailed review of environmental accounting, in addition to understanding the nature of environmental disclosures for industrial and extractive companies in Yemen and the extent of their application to international accounting standards. The research recommends the necessity of obligating industrial and extractive companies to environmental disclosure due to its low levels in the annual reports they issue, which reflect a state of lack of interest and awareness by the majority of Yemeni companies of their environmental role and responsibilities towards society. 
Keywords. INTERNATIONAL ACCOUNTING STANDARDS (IFRS \& IAS) - DISCLOSURE ENVIRONMENTAL - YEMENI INDUSTRIAL AND EXTRACTIVE COMPANIES.

\section{Introduction}

Accounting is a profession that has the duty to elevate the internal view of any economic unit and to develop information that clarifies its role within its environment and its contribution to providing appropriate information for making decisions that result in optimal utilization of resources, preservation of the environment and averting danger from it.

There is no doubt that the development in the economic activities of companies, as well as the accelerating complexities in production techniques in the world, have led to an increase in the negative effects of economic activity on the natural environment. , which prompted most countries of the world to find mechanisms to reduce the problem of environmental pollution. On this basis, many countries of the world impose special requirements for environmental measurement and disclosure applied by industrial companies, through which environmental information related to the environmental effects of economic activity is shown on the one hand, and on the other hand, it is shown The remedial measures implemented by the company to reduce or limit these effects, that the environmental disclosure in the financial statements did not take sufficient attention as a result of the lack of need for this type of information, but with the increasing social pressures towards the availability of information about the company's activities in

\section{Research Methodology / Research Problem} The main problem of environmental accounting is reflected in the lack of disclosure of information and costs related to environmental protection, as many factories and companies integrate these costs within industrial costs, and others include them in the income statement independently. Hence, the protection of the environment and the proper exploitation of its resources fall on the shoulders of these units, in addition to the main role that the state plays in this field. In order to provide the conditions and requirements that allow the possibility of conscious dealing and to avoid these problems, these units should unite their efforts in the field of recognizing their obligations towards the environment. In addition to its industrial obligations, in addition to its positive role in reducing the environmental effects of its industrial activity, and accordingly, the research problem lies in the deficiency of the accounting system applied in protecting the environment and this was noted in each of the two summits London and Pittsburgh for G20 leaders in 2009.G20 leaders reinforced the impact of the International Financial Reporting Standards (IFRS) by calling for the implementation of global accounting standards by 2011. By the end of 2008, more than 100 countries had adopted IFRS (Cabrera. 2008; Barth. et al 2008) The other parallel summit was the United Nations Special Summit on the Environment, which was held on September 22, 2009. The United Nations summit confirmed the link between environment and finance in the said summit. Especially after the implementation of the Kyoto Convention to reduce pollution, which imposes on countries to reduce the percentage of industrial pollutants for companies, which is expected to be amended in the 2015 Paris Agreement, which discusses climate change, it became important to specify the requirements for environmental disclosure for industrial companies to meet their main purpose. Providing information on the nature of the company's environmental activities is of interest to multiple internal and external parties. From this point of view, the current study will shed light on the requirements for measurement and disclosure of environmental information under international accounting standards, in addition to measuring the actual level of disclosure for industrial and forestry companies in Yemen.

economic units in general and industrial units in particular in determining and measuring environmental information and disclosing it in the financial statements and statements prepared accordingly. The system compared to the requirements of measurement and disclosure of environmental information prepared in accordance with international accounting standards, which reduces its transparency and credibility.

\section{The research importance}

The importance of the current study stems from the importance of accounting from environmental performance through its role in providing environmental information necessary for rationalization in the decision-making process, so its application in industrial units is of great importance and necessity. In addition, the current study contributes to achieving the following:

1- Attempting to identify and measure the areas harmful to the environment in order to identify the 
units to the extent of their contribution to those damages and their role in limiting them.

2- Preamble for Yemeni industrial units to disclose their environmental performance as part of their obligations towards the environment, whether forced or voluntary.

3- Giving these environmental fields a position within the accounting system to improve the measurement of environmental performance in performing its functions in providing useful information to serve the environment and society and saving them from the dangers of pollution.

4- Finding the means and ways to address the internal damages by highlighting the reality of the environmental performance of the industrial units operating in the country and determining the costs of protecting the environment and following the best procedures for measuring those costs in order to obtain the best results.

\section{The study aims to}

1.Determining the requirements for environmental measurement and disclosure of environmental information in the financial statements under international accounting standards

2. Study and determine the degree and nature of disclosure of environmental information in the financial statements of industrial and extractive companies in Yemen.

\section{Study hypothesis}

The current study attempts to test the following hypothesis: The accounting system applied in industrial and extractive companies in Yemen provides a certain level of environmental disclosure in their annual reports under international accounting standards.

\section{Method and sources for obtaining data}

The inductive approach was relied upon in preparing the theoretical side of this study by making use of Arab and foreign scientific sources. As for the practical side, it was relied on the information announced in the annual reports of the companies. The content analysis method will be the basic measurement tool for the research, as the disclosure scale will be prepared using this method and in a similar way to the 1982 Wiseman scale, which includes 18 axes of environmental disclosure in the financial statements. In order to enrich the study with all that is new in the field of environmental performance accounting, the researcher relied, in addition to books, periodicals, references, research and working papers, which dealt with the subject in Arabic and English. in reducing environmental pollution.

\section{- First - the theoretical framework of the research}

\section{-The concept of accounting disclosure of environmental performance}

The traditional accounting disclosure does not fully reflect the environmental impacts arising from the practice of industrial establishments, not their multiple activities, at the same time that information about the activities performed by industrial establishments within the framework of their responsibility towards the environment has become a basis upon which to draw up strategies and programs aimed at contributing to the protection and sustainability of the environment. Environmental disclosure comes as a sense of the investors' need for information about the environment, to counter the traditional disclosure's shortcomings in meeting these needs. Therefore, unremitting efforts are being made by legislative institutions and professional organizations in many countries of the world towards enacting legislation requiring the disclosure of such information.

One of the statistics indicates that $70 \%$ of American economic establishments disclose environmental information in their annual reports, thus occupying the first rank in the world over economic establishments in Europe that are trying to catch up. Helen \& Gray, 2001:100-101. In view of the above, there is an urgent increase in the development of the disclosure standard in accounting thought to include environmental disclosure, which leads to an increase in the efficiency of information operation by decision makers and helps in rationalizing their decisions related to the assessment of social and environmental responsibility. . Accounting disclosure is defined as a set of information items related to the performance and activities of environmental management of economic institutions and their financial implications in the past, present and future (Deegan 2009: 282, 2009).

Accordingly, the environmental disclosure of companies means: that disclosures related to the company's activities have an impact on the natural or physical environment in which it operates (Wilmshurst and Frost, 2000:16). 


\section{- Criteria for the selection of disclosed environmental information}

The effects of disclosure on the environment face the problem of testing information that ensures its proper output to those who are interested in identifying the environmental performance of the institution. The following is a list of the most important of these criteria (Andreas \& Upasena, 1998:62):

\begin{tabular}{|l|l|}
\hline Standard & \multicolumn{1}{|c|}{ Definition } \\
\hline Understandability & $\begin{array}{l}\text { It is a characteristic that requires that the language in which } \\
\text { environmental information is formulated be characterized by } \\
\text { simplicity and clarity in order to facilitate their understanding. }\end{array}$ \\
\hline$\underline{\text { Relevance }}$ & $\begin{array}{l}\text { It is a characteristic that requires that the information be } \\
\text { essential for its users from among the decision makers, in } \\
\text { addition to that it should include assurances about the } \\
\text { performance of the facility for the past period and predictions of } \\
\text { behavior created in the future. }\end{array}$ \\
\hline Reliability & $\begin{array}{l}\text { It is a characteristic that means that the measurement and } \\
\text { presentation of information is free from fundamental errors or } \\
\text { biases for any of the beneficiary parties, in addition to the fact } \\
\text { that it should be limited to presenting the necessary information } \\
\text { exclusively without going into the boring details that cause the } \\
\text { loss of the basic information and then the absence or at least the } \\
\text { lack of The intended benefit of disclosure }\end{array}$ \\
\hline Comparability & $\begin{array}{l}\text { It is a property that requires the disclosed information to be } \\
\text { characterized by the comparability of the performance of the } \\
\text { same facility at the level of successive periods of time, and the } \\
\text { comparison between the performance of the facility and its } \\
\text { developments that are engaged in activities similar to that of the } \\
\text { same facility, as well as the need to disclose the methods. }\end{array}$ \\
\hline
\end{tabular}

\section{- Environmental accounting disclosure mechanisms:}

Information related to the environment can be communicated to the community and its stakeholders through a set of mechanisms that can be summarized as follows (Abu Al-Azm, 49: 2005):

Voluntary disclosure: that the knowledge of the shareholders' participation in the management of the institution leads to two important problems:

First: there is asymmetry in the information, the investors are less knowledgeable compared to the management about the activities and value of the institution.

The second: the existence of ethical risks, as the administration works to take advantage of the advantages of its knowledge of the activities of the institution and its future prospects. Therefore, the administration must have incentives for voluntary disclosure of information other than what is required by the standards for preparing financial statements. His role in improving the economic performance of the institution, its reputation, and its competitive value in capital (Toms, 2002:257). Although the environmental report and disclosure is still optional in most cases, many large companies in developed countries have voluntarily initiated the application of environmental accounting laws and standards and developed environmental management systems and put environmental reports within the annual reports, despite the shortcomings that taint the validity of the reports of some institutions that Focusing on the positive side, neglecting the side that negatively affects future revenues and cash flows and those that 
expose them to legal penalties and fines (Rwani, 2007, p.: 125)

Compulsory disclosure: This type of disclosure is imposed on industrial establishments and in accordance with the laws, regulations and administrative regulations in the capital markets, and in accordance with accepted accounting standards, as a general purpose in professional accounting groups.

\section{- International Accounting Standards (IFRS \& IAS) related to environmental activity:}

\begin{tabular}{|c|c|}
\hline International Accounting Standards (IAS) : & $\begin{array}{l}\text { International Financial Reporting Standards (IFRS) for } \\
\text { financial reporting: }\end{array}$ \\
\hline $\begin{array}{l}\text {-International Accounting Standard } \\
\text { (1 AIS) Presentation of financial statements . } \\
\text {-International Accounting Standard (AIS 16) property, } \\
\text { plant and } \\
\text { Equipment. } \\
\text {-International Accounting Standard No. (AIS 37) } \\
\text { Provisions for Contingent Liabilities and Contingent } \\
\text { Assets. } \\
\text { - - IFRS } 34 \text { Interim Financial Reporting determines the } \\
\text { appropriate amount of provision, such as product } \\
\text { warranty provisions, environmental costs provisions, } \\
\text { and worksite repair costs. }\end{array}$ & $\begin{array}{l}\text { Financial Reporting Standard (6 IFRS), which deals } \\
\text { with exploration assets and the evaluation of mineral } \\
\text { resources, and stipulates that the company recognize } \\
\text { any obligations for removal and restoration that the } \\
\text { company incurs during a certain period as a result of } \\
\text { its exploration or evaluation of mineral resources. } \\
\text { Those are in accordance with IAS } 37 \text { Provisions, } \\
\text { Contingent Liabilities and Contingent Assets }\end{array}$ \\
\hline
\end{tabular}

\section{- Second: the applied aspect of research}

\section{The reality of environmental disclosure in industrial and extractive companies in Yemen}

Description of the Disclosure Scale: Content Analysis: Determining the level of disclosure in general and environmental disclosure in particular is usually done using the content analysis method, and content analysis is a technique used by researchers to measure behavioral phenomena that can be directly quantified because it mostly depends on the narrative or narrative method of expression about her. In addition, content analysis is a research method that makes inferences from the data reproducible to activate optional environmental disclosure variables (Almagtome, 2015). Moreover, the content analysis method is a method of modifying the text or content of a piece of writing into different groups or genres based on the criteria selected (Weber, 1988). In this regard, then determining the environmental disclosure of companies by analyzing the content of the annual reports of the industrial companies, the research sample based on the presence or absence of data related to environmental disclosure into (6) categories of environmental concepts, which are:

(Disclosure related to environmental expenses and risks - compliance with environmental laws and instructions - pollution control - sustainable development - land pollution treatment - disclosure related to the management of environmental activities).
The content analysis technique has been adopted in this research because it allows the environmental disclosure of the comparative companies and to classify them on a regular basis, which is useful for determining the trends and extent of disclosures. Moreover, this technique is one of the most systematic, objective and quantitative technical methods of data analysis used in previous research and studies involving corporate environmental disclosure practices (Wiseman, 1982, et.al) and it is also one of the most common or dominant research techniques used To measure and analyze the environmental disclosure of companies based on their annual reports.

Since the end of 1990, various reports related to the environmental performance of companies have become prevalent tools for communicating with the concerned parties such as the public, the beneficiary parties. Nowadays, due to the importance of disclosing environmental performance reports and sustainability reports, the demand for them has increased from the various stakeholders regarding the various information assets of companies. As the disclosure of companies through environmental performance reports and sustainability reports in a form of communication related to environmental information and sustainable development, and through these annual reports through which 
companies inform the concerned parties on the types of issues or indicators that indicate that companies have improved their performance or It changes according to its policies and strategies (27. Bae, 2009, p).

\section{Environmental Disclosure Index:}

Most researchers in the field of environmental disclosure have relied on the coding method as a tool to determine and measure the level of environmental disclosure for industrial and extractive companies in their annual reports (Wiseman 1982 \& Commier, et.al). When using this method, the focus is primarily on the items and topics related to disclosure, which are important issues for the beneficiary parties, rather than focusing on the number of words or the number of sentences contained in the report to be evaluated. This is done by identifying a certain number of areas of environmental disclosure or issues that are concerned with determining whether the areas that have not been discussed or addressed by company managers in the environmental disclosure of the numbers of annual reports. Therefore, the disclosure indicator used classifies the disclosure areas into items and assesses the presence or absence of each of the items specified in the environmental disclosure index using the coding methodology (yes or no).By using this type of distribution, we will avoid many potential problems that arise from the use of other means such as the number of words, topics, paragraphs and pages. Although the distribution methodology used does not measure the environmental information that is disclosed in the annual reports, it is not essential to identifying the quality of the disclosed information, but its aim is to recognize the existence of each item of disclosure.

\section{Table: Components of Disclosure}

\section{Scale}

\begin{tabular}{|c|c|c|}
\hline $\begin{array}{l}\text { 1-Environmental Expenditure and } \\
\text { Risk Disclosure: } \\
\text { - Investments in the field of } \\
\text { environmental protection } \\
\text { - Environmental Expenses } \\
\text { - future environmental investments } \\
\text { - future environmental expenses } \\
\text { - environmental obligations } \\
\text { - Reserves for future risks } \\
\text { - Reserves for future } \\
\text {-environmental expenses }\end{array}$ & $\begin{array}{l}\text { 3- anti polution : } \\
\text { - emission of environmental } \\
\text { pollutants } \\
\text { - Treating environmental pollution } \\
\text { - Production waste management } \\
\text { - Availability of means of } \\
\text { controlling pollution } \\
\text { - Noise and odors polluting the } \\
\text { environment } \\
\text { - Energy consumption } \\
\text { - Energy savings used }\end{array}$ & $\begin{array}{l}\text { 5- pollution treatment } \\
\text { - Work site waste removal } \\
\text { - Pollution Remediation Efforts } \\
\text { - Future obligations related to the } \\
\text { workplace } \\
\text { - Leakage of harmful substances to } \\
\text { the environment }\end{array}$ \\
\hline $\begin{array}{l}\text { 2- Compliance with environmental } \\
\text { laws and regulations: } \\
\text {-Environmental lawsuits } \\
\text { - current and future prospects } \\
\text { - Environmental fines and taxes } \\
\text { - environmental accidents } \\
\text { - Treating environmental damages }\end{array}$ & $\begin{array}{l}\text { 4-sustainable development } \\
\text {-sustainable development } \\
\text { - The amount of consumption of } \\
\text { natural resources } \\
\text { - recycling }\end{array}$ & $\begin{array}{l}\text { 6- Disclosure related to the } \\
\text { management of environmental } \\
\text { activities } \\
\text { - Company's environmental } \\
\text { policies } \\
\text { - Setting environmental goals } \\
\text { - Environmental audit in the } \\
\text { company }\end{array}$ \\
\hline
\end{tabular}

Score:( Cormier, 2012:39, \&wiseman,1982,:56)

For the purpose of determining the level of disclosure, the scale used in this study depends on a four-level quantitative indicator (0.1.2.3) when using the content analysis method, and this mainly depends on the degree of environmental disclosure that is announced in the annual reports of industrial companies. The scale includes 29 items for measuring the level of environmental disclosure, as the items are grouped into 6 categories as shown in the table above. This classification is based on a score ranging from one to three, and grade (3) is awarded for quantitative disclosure items, grade (2) for qualitative disclosure items, grade (1) for disclosure items in general, and finally (0) is awarded for items where environmental disclosure is not available. Content analysis includes reviewing the annual report of the sample companies, searching for the presence or absence of data related to environmental issues (Wiseman, 1982). By using this technique, the disclosure of this information is recorded only once (because repeated information does not lead to a high degree of the environmental disclosure index). Based on what was mentioned above, the annual reports of industrial and extractive 
companies were studied, the research sample, using the content analysis

technique, and then items related to environmental disclosure were determined after awarding grades based on the level of disclosure (quantitative, qualitative, general). The previous table shows the items related to home disclosure in detail to what was mentioned above in the table, and these items were divided on the basis of two sources of terminology.

\section{Research hypothesis test results}

Through the annual reports of Yemeni companies, it is clear that there is a discrepancy in the level of environmental disclosure of the sample companies, where the highest level of environmental disclosure reached $11 \%$ and was in favor of the Chemical
The first is the environmental disclosure index itself, which includes six different categories, and the second source is the accounting literature related to environmental disclosure terms, especially (Glavi \& Lukman, 2007), which discussed the details and conditions related to sustainability and its definitions, distributed in 6 categories, and each period contains 10 Clauses related to environmental disclosure.

Industries Company and the electronic and metal industries sector, and the lowest percentage was $6 \%$ for the Packaging Company and the Construction Materials Industry Company. Based on the foregoing, it can be said that the basic hypothesis of the research is accepted, which states the following:

\section{The accounting system applied in industrial and extractive companies in the Republic of Yemen provides a certain level of environmental disclosure in their annual report}

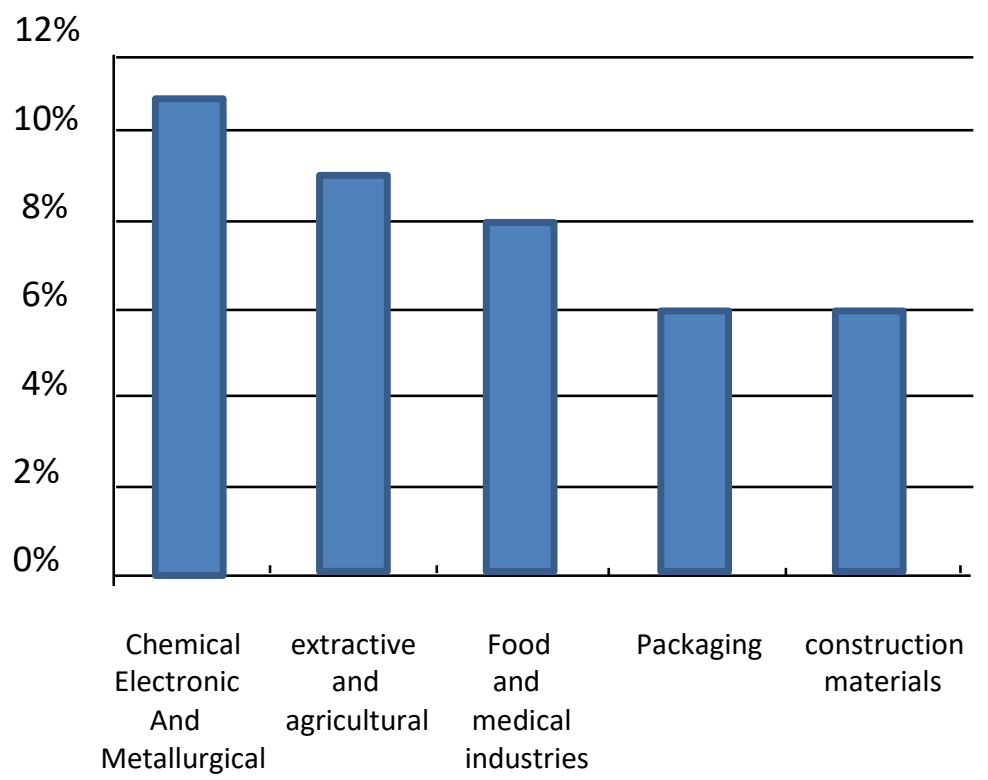

Distribution of environmental disclosure results by sector

It is clear from the financial statements (annual reports published in official newspapers and company websites) for Yemeni companies announced at the end of the fiscal years (2019-2020) that the chemical industries sector and the electronic and metal industries sector have witnessed the highest environmental disclosure rate, as they reached $11 \%$ of the volume of environmental disclosure, being environmentally sensitive companies compared to other companies that are less sensitive to the environment and the reason for this is due to the materials used by these companies have a significant impact on the environment, followed by the Extractive and Agricultural Company, which amounted to almost $9 \%$, and then followed by the Food Industries Company and the Medical Materials Company, as it reached They account for $8 \%$ of the volume of environmental disclosure, and finally, the volume of environmental disclosure in the Packaging Company and the Construction Materials Industry Company, as the volume of environmental disclosure for them reached $6 \%$ and $6 \%$, respectively.

\section{Conclusions}


The research reached a set of conclusions, the most important of which are summarized in the following points:

1- The study provided a theoretical framework for understanding the nature of environmental accounting and reporting by providing a detailed review of environmental accounting and the history of reporting, in addition to understanding the nature of environmental economies by industrial and extractive companies in the Republic of Yemen, the study sample, and the extent of their application to international accounting standards.

2- Environmental disclosure is one of the components of comprehensive disclosure as it meets the needs of the users of the lists

Financial information that enables them to assess the environmental performance of the enterprise.

3. The results of the study showed that environmental disclosure in Yemeni industrial companies is restricted by what the government imposes

Regarding the disclosure of fuel or production residues.

4. The results of the study showed that there is an optional disclosure of information related to the environmental activities of the Yemeni companies in the research sample in varying proportions among the sample companies.

5. The disclosures made by some companies are limited and come in the context of obtaining a quality certificate, but none of the industrial companies disclosed to the sample what they are doing regarding the environment in terms of accounting, disclosure and transparency.

6- There is a wide gap between the reality of the accounting system applied in the institution and the requirements of accounting standards

International standards represented by the lack of disclosure in the financial reports and some gaps in the preparation of these reports.

7- The application of the environmental accounting system in Yemeni industrial and extractive companies did not receive sufficient attention, and this comes as a result of the lack of awareness of industrial companies and their weak contribution to the responsibilities that they must bear in the field of protecting the environment and society.

\section{Recommendations}

Based on the findings of the study, the researcher recommends the following:

1- The necessity of emphasizing the interest of corporate management in the industrial sector in scientific methods of environmental accounting

And work to develop the skills of employees through the preparation of special courses for accounting cadres in this field.

2. The necessity of applying a unified method for expressing and disclosing environmental performance that all companies are committed to

Yemeni industrial and extractive.

3- Commitment to the requirements of the application of international accounting standards in a manner consistent with recent developments, including the requirements of inter-accounting.

4- Working to spread environmental awareness among all parties interested in environmental affairs, whether for communities or

Officials or institutions and their employees, especially managers and accountants.

5- The need to consider the environmental performance of industrial companies as one of the important axes in evaluating their environmental performance on the

Considering that improving environmental performance fundamentally affects the rest of the other aspects of the organization (financial

management, marketing, internal improvement and growth).

6- The need for effective cooperation between industrial companies, the Ministry of Trade and Industry and the Ministry of Environment in training accountants on environmental accounting applications in Yemeni industrial companies. 
7- Factories must carry out periodic checks in the vicinity of the factory workers, as determined by them

The law, and the examinations must include all group of toxic substances used in production or stored

in the factory.

8- The necessity of obligating industrial and extractive companies to disclose the environment due to its low levels in the annual reports they issue, which reflect a state of lack of interest and awareness on the part of the majority of companies of their environmental role and responsibilities towards society.

\section{References :}

1 Chen. JC., and Chen JC. (2009). The Accuracy of financial report projections of future environmental capital expenditures. American Accounting Association Conference. New York. [Online]

Available:http://aaahq.org/AM2009/abstract.cf $m$ ? submissionID=2250.

2- Cho. C., Freedman. M., and Patten. D. (2009). Corporate disclosure of environmental capital expenditures: Atest of alternative theories. American Accounting Association Conference. Abstract [Online] Available:http://aaahg.org/Am2009.

3- Al-Amin Maher Daoud, Samia, one of the impact of stakeholder pressure on a level that builds environmental management accounting practices, a field study on Syrian industrial companies, "Tishreen University Journal for Research and Scientific Studies, Economic and Legal Sciences Series, Issue 115,2014,36: $p$. 4- Al-Styri Muhammad Saeed, Intermediate Accounting, Environmental Protection Society, Kuwait, 1989.

5- Abu Al-Azm, Fahim Muhammad, Obstacles to Environmental Disclosure in Financial Reports, a Republic Case Study

Arab Egypt Journal of Public Administration, Imam Muhammad bin Saud University, Riyadh, Saudi Arabia, Volume 45, Number One, February 2005.

6- Al-Qattan, Walid Abdul-Aziz, "Evaluation of the disclosure of environmental costs in the Kuwaiti shareholding industrial companies, Journal of Accountants, Accountants and
Auditors Association, Kuwait, Issue: 6.2009.42 p.

7- Matar Muhammad, Al-Suwaiti, Mousa (2012) Sustainability Accounting - Conceptual Framework and Its Applications in Professional Practice, advanced research to the quarterly scientific conference entitled Creativity and Excellence in Business Organizations, April 2030, 2012, University of Applied Sciences College of Economics and Administrative Sciences, Jordan.

8. Bennett, M., Bouma, J. J., \& Wolters, T. (2004). Environmental Management Accounting : Informational And Institutional Developments. New York, Boston, Dordrecht, London, Moscow.

9. Burritt, R. L., Hahn, T., \& Schaltegger, S. (2002). An Integrative Framework of Environmental Management Accounting Consolidating the Different Approaches of EMA to a Common Framework and Terminology. In M. Bennett, J. J. Bouma, \& T. Wolters, Environmental Management Accounting: Informational and Institutional Developments. Dordrecht: Kluwer Academic Publishers.

10. Deegan, C., (2009) "The accountant will have a central role in saving

the planet really? $A$ reflection on green accounting and green eyeshades twenty years later", Critical perspectives on accounting journal, No. 24,

P. 450.

11. Gray. R. H., Bebbington, K. J., \& Walters, D. (1993). Accounting for the Environment: The greening of accountancy (Part I/ ed.). London: Paul Chapman.

12.IFAC." International Guidelines on Environmental Management

Accounting". the International Federation of Accountants, August, (2005).

(http://scholar.google.com)

13. Lamberton, G. (2005). Sustainability accounting "A brief history and

conceptual framework". Accounting forum, 29(1), 7-26

14. Office of pollution and toxics, (1999), United states Environmental

Protection Agency, Case Study: Green Accounting at $A T$ \& TEnvironmental accounting Washington, D.C. No. 712-R-95003, PP10-15.

15. Peskin, H. M. (1989): A Proposed Environmental Accounts Framework, in Ahmad, YJ, Serafy, S. $E$ and Lutz, E. (Eds) Environmental Accounting for Sustainable Development, Washington, DC the World Bank. 
16. Peter lemathe, Roger k Doost" (2000). Environnemental cost accounting and auditing", Managerial Auditing journal, Vol 15, No.8, pp 424-431.,http://www.emeraldinsight.com.

17. Roberts, R. W. (1992). Determinants of Corporate Social Responsibility Disclosure: An Application of Stakeholder Theory. 17(6),

595-612.

18. Roger L.Burritt, "Business Strategy and the environment", Vol.13, Issue:1, 2004.p13.

19. Scavone, GM. "Challenges In Internal Environmental Management

Accounting Reporting In Argentina", Journal of Cleaner Production 14,

2006, 1276-1285.

20. Schaltegger, P.D.S tefan \& Burritt, Roger, contemporary Environmental Accounting: Issues, Concepts and Practice, U.S.A,

October 2000.

21. Schaltegger, S. and Burritt, R.L. (2000): Contemporary Environmental Accounting Issues, Concepts and Practice. UK: Greenleaf Publishing.

22. Schaltegger, S., \& Burritt, R. L. (2000). Contemporary Environmental

Accounting - Issues, Concepts and Practice. Sheffield: Greenleaf Publishing.

23. Schaltegger, S., Müller, K., \& Hindrichsen, H. (1996). Corporate

Environmental Accounting. London: John Wiley \& Sons.

24. Steele, A. P. and Powell, J. R. (2002): Environmental Accounting:

Applications for Local Authorities to Quantify Internal and External Costs of Alternative Waste Management Strategies. Environmental Management Accounting Network Europe, Fifth Annual Conference,

Gloucestershire Business School, 11/12 February.

25.UNDSD. "Environmental Management Accounting: Procedures and

Principles", United Nations Division for Sustainable Development, New

York. 2001. 25. Wiseman, J. (1982). An evaluation of environmental disclosures made in corporate annual reports. Accounting. Organizations and Society, 7(1), 53-63. 